\title{
Challenging Traditional Gender Roles - Women Empowerment through Ornamental Fish Farming
}

\author{
Jane Jacob ${ }^{1 *}$, P. Abinaya ${ }^{1}$, R. Thirunavukkarasar ${ }^{1}$ and Sangavi, S. ${ }^{2}$ \\ ${ }^{1}$ Department of Aquaculture, ICAR-Central Institute of Fisheries Education, Mumbai, India \\ ${ }^{2}$ Trichy Centre for Sustainable Aquaculture, Tamil Nadu Dr. J. Jayalalitha Fisheries University, Trichy, Tamil Nadu, India
}

*Corresponding author: jane2012maria@gmail.com (ORCID ID: 0000-0002-6917-3378)

Received: 24-11-2020

Revised: $14-02-2021$

Accepted: 10-03-2021

\begin{abstract}
In the contemporary world, ornamental fisheries /aquaculture is gaining much popularity; in fact, globally it is a trading and marketing industry rather than a hobby. Earlier days, ornamental aquaculture in India was just a hobby for people. Slowly the hobby got momentum to be a viable business as it boomed with trade values internationally. India has enormous potential to be one of the top ornamental fish producing nations as it has huge in untapped or unexploited resources. Ornamental aquaculture can generate income and employment and has immense potential for the upliftment and empowerment of women. Women in fisheries is predominantly involved in post-harvest activities but inclusion of women in aquaculture will help in creating gender equalisation in the sector. Ornamental aquaculture has been tried and tested by several countries, states, and organisations in rural development and the progress of women in all walks of life through ornapreneurship.
\end{abstract}

\section{Highlights}

(0 There are several technologies for women empowerment today but ornamental fish farming help women in empowering herself while helping in maintaining her happiness and reduce stress.

Keywords: Women empowerment, Ornamental aquaculture, Gender equalisation, Aquaculture

The culture of ornamental fish or aquariculture is simple, easy to understand, takes less time and cheap labour required in comparison to any other forms of aquaculture practices. Moreover, India has vast potential in ornamental fish production due to presence of rich biodiversity of more than 250 species and favourable climatic conditions but is $31^{\text {st }}$ in world ranking with annual trade of just US \$ 1.6 million (Raja et al. 2019). In the global scenario, neon tetras, gold fish, angel fish and Discus dominate the trade but our indigenous fishes are highly potential. Hence, women from ecologically sensitive areas can support in the protection of the endangered ornamental fishes in terms of backyard culture and also help in development of ornamental fish trade sustainably.

Women have the potential and capacity to successfully manage any type of enterprise because of her parental/ motherly instincts. A women enterprise is defined by the government of India as an enterprise in which at least $51 \%$ of capital is in the financial interest of women and a minimum of $51 \%$ of the employment generated

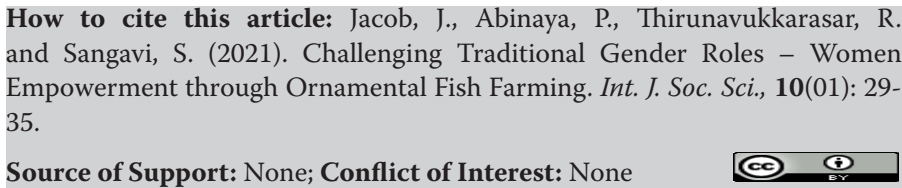


goes to women (Sharma, 2013). Women is pulled back by the innumerable responsibilities on her shoulders while being prevented by several taboos and myths pertaining to women (Singhal, 2016). Nevertheless, she is forced by the patriarchal society to limit her dreams citing her commitments to her family and the welfare, growth of her children. Empowering women must never be considered as a charity or a means to poverty alleviation but, it is the empowerment of generations to come, as she will inspire children and grandchildren (Nune, 2008). The aquaculture sector is itself a lucrative option for woman and community development. It is sustainable and can also contribute to the national gross production. This paper focusses on the role of ornamental aquaculture in woman upliftment and a few success stories.

\section{Women in the Fisheries Sector}

Employment of women in the fisheries sector has existed since time immemorial (Harper et al. 2017). Nowadays, women are more involved in the aquaculture sector than in the fisheries sector contributing to $19 \%$ and $12 \%$, respectively FAO (2020). Fish and fish products are an integral part of many cuisines around the world. Women are active in both artisanal and commercial fishery sectors in some regions and even dominating certain activities such as cleaning and marketing. Their activities range from shallow water fishing to waged labour. In some cases, she comes in with pride as a member of her fishing community, sometimes she is pushed by pain and poverty after losing her loved ones, otherwise she is forced to earn for her family as no one else would. Whatever be the cause, her involvement and employment in fisheries will be within the shore such as seining, mending nets, seaweed cultivation, collecting bivalves clinging to the rocks, cleaning and selling fish, drying fish, etc. in the male-oriented fisheries sector. Women casting nets in the sea/ocean is a rarity and even barred in certain communities (Mathews, 1993). These women have been supporting the economy of her house through her involvement in possible areas in the fisheries sector. Be it the west or the east, the role of women is always in the processing or post-harvest particularly during the peak of the herring fishery, atlantic cod fishery, Chakara fishery, etc., and rarely in decision making and exploitation of the resources, as they are given stable or poorly paying jobs (Harper et al. 2017; FAO, 2020). Women take up 58\% of the activities in the post-harvest sector and with no differences found in inland regions also. Areas where aquaculture is prevalent, she is assigned to make the feed, mend the nets and bird scare and occasionally sell the produce. On the contrary, the economic, scientific development and increased demand for shell fish, bivalves and molluscs has led to creation of laws, rules and principles on the hygienic handling of fishes reducing the selfemployment opportunities for women in post-harvest handling of fishes particularly in the less developed nations such as Africa and South-East Asia. Aquaculture can help women in running her own enterprise, take her own decisions, and manage the accounts book herself giving her a sense of ownership and power (FAO, 2020). This will help change the gender outlook in traditional fisheries and aquaculture policies and create more opportunities for women globally (Table 1).

\section{Ornamental Aquaculture - Past and Future}

Ornamental fish keeping has been a recreational activity for many people but it can also give a financial outcome. So, hobbyists started their own farms at homes that can create employment and livelihood opportunities for other people as well. Subsequently, the ornamental fish sector gained more attention due to high demand and rapid growth of the export market and trade. The total global ornamental fish trade has been estimated to be more than US\$ 15 billion (Raja et al. 2019). But, India's contribution to the global trade is insignificant even though India is blessed in the biodiversity of ornamental fishes with more than 100 indigenous species. There are lacunae in the breeding of indigenous ornamental fishes, which makes India contribute less to the total global ornamental fish market. Many NGOs and institutes provide hands-on training on various aspects such as breeding techniques, information on the feed used, method and frequency of feeding, water exchange particulars, growth rate, fecundity, mortality, hatching rate, marketing particulars to the rural women (Raja et al. 2014). Total ornamental fish production can be 
Table 1: Traditional role of women in fisheries \& Aquaculture sector of different countries

(Siason et al. 2013 and Harper et al. 2017)

\begin{tabular}{ll}
\hline Country & Role of women in fisheries/aquaculture \\
\hline Europe & Processing \\
East Africa- Mozambique, Congo & Gleaning, Fish trade, repairing and mending nets \\
Africa- Comoros islands & Handpicking during low tide \\
West Africa & Processing, financing and trade \\
Tanzania & Seaweed farming, octopus trapping \\
America- Nova Scotia and Newfoundland & Post-harvest \\
Mexico, Central and South America & Aquaculture, processing and, marketing \\
Pacific island countries & Fish catching and processing \\
Cambodia & Gear making, cleaning, catching, processing, marketing \\
Lao PDR & Fishing, culture, harvesting, post-harvesting, marketing and fish processing \\
Vietnam & Processing and other labor \\
Indonesia & Pearl oyster, seaweed culture, paddy cum fish culture systems, etc \\
Malaysia & Feed preparation and maintenance of fishes/prawns in cages \\
Sri Lanka & Seining, Fish processing and marketing \\
Bangladesh & Seining, Fish processing and marketing \\
India & Seining, Seaweed culture, fish seed and fry collection \\
Nepal & Laying out and Mending of gear, harvesting and marketing catch \\
\hline
\end{tabular}

increased by the establishment of backyard hatcheries by women SHGs or fisherwomen cooperativesor other organisations. So, it is essential to speed up ornamental fish production with women entrepreneurs in the near future throughout the world.

\section{Potential for Women in Ornamental Fish Culture/ Fisheries}

As in the several other sectors, women have been consistent in pushing her boundaries in the fisheries and aquaculture sector too. When her opportunities were taken away by mechanisation and industrialisation, she was empowering to do something better thereby increasing the standard of her life. Ornamental fish culture is found to be most suitable for women, as this sector has increasing domestic and global demand and its ability to be adapted to small scale and large scale will make this industry a lucrative business option (Goswami, 2011). It has been increasingly attracting the interests of several women who want to make it big in this competitive world (Pandey and Mandal, 2017). In India, central and state governments as well as multiple non-governmental organisations are active in promoting women in the ornamental fish rearing sector. Recently, (PMMSY- Pradhan Mantri Matsya Sampada Yojana) boasts several beneficiary based activities for women in seaweed cultivation and as well as in ornamental fish culture.

\section{Backyard Ornamental Fish Culture and Women - A Saga of Success}

The backyard small-scale ornamental fish culture enterprise is relatively stable and is most popular in southern states of India. According to NFDB (National Fisheries Development Board), a backyard unit is involving any house hold or SHG members who have sufficient backyard area, and availability of resources for maintenance of the fishes. The practice of ornamental fish culture is claimed to be a lucrative business by women in villages and cities alike and are generally willing to adopt innovations and technologies considering the economic advantages, Backyard ornamental fish culture enterprise do not add to their drudgery for a women because of its convenience in operation (Shaleesha and Stanley, 2000). For a housewife, it gives a sense of becoming an earning member of the family and a 
woman working odd jobs to make ends meet, it is an escape from her daily toils and provide an additional income. All the states in India as well as the central and state institutes promote ornamental fish culture among women. It is the unified responsibility of all people to uplift the downtrodden and needy, especially women. In the state level, the fisheries departments, SAUs join hands to implement the schemes and such institutes of notable mention among them are NFDB, KVK, MPEDA, CIFA, CMFRI, CIFE, KUFOS, TNJFU, etc.

The above institutes conduct training programmes on various aspects of ornamental fish culture, breeding, larval rearing, feed management, live feed culture, pond/tank maintenance, fabrication and maintenance of glass aquaria and disease management (Satam et al. 2018). Also, they arrange exposure visits to successful women entrepreneurs because of the concept "seeing is believing". They are also given classes on the funding opportunities provided by the various financial organisations and their method of funding and repayment. On successful completion, potential and interested candidates are provided with brood fish/ seeds and certain basic necessities to arouse an interest in them. There are also frequent follow-up visits by resource persons to take account of their progress in post-training.

\section{Model Training Programmes}

There will be regular trainings in many state run universities in collaboration with the respective fisheries departments/funding agencies. The latest is the inauguration of the school for ornamental fish farmers by ICAR-CIFA in West Bengal. One of the most successful training programme is the 'Kumbalam' model in Kerala under the supervision of Dr.T.V.Anna Mercy (Mercy and Kumar, 2014). As there is not much of the reports have published literature, we are briefing about few selected trainings in the following pages.

\section{Kerala}

Kumbalam is a village in Ernakulam district of Kerala. Here, the training was imparted through a series of lectures, audio-visual aids, field visits and practical demonstration. The principle of learning by doing was the process of adoption of different breeding technologies. Overall, 293 beneficiaries both men and women from the villages were selected and were given training for the breeding and culture of ornamental fishes. They were able to make a profit of ₹ 55,000/year. In post training, $61 \%$ of the women took up the ornamental fish culture as their full-time business. Thus, with this project, they were able to develop Kumbalam, a normal fishing village into an "ornamental fish village", catering to the aquarium shops in and around the district. In addition, KAVIL (Kerala Aqua Ventures International Limited), India's first public-private limited company established in year 2010 exclusively for the ornamental fish industry (Satam et al. 2018) was set up by the ornamental fish farmers and owns the majority share.

\section{West Bengal}

West Bengal is a pioneer state in ornamental fish culture in India. West Bengal is the leading state in export and domestic markets (Ghosh et al. 2003). This state is highest in human resource exploitation and around 20 to 30 thousand women fishers are actively involved in this sector. This is also highest in number of women cooperative societies and SHGs on ornamental fish culture and are running successfully in the state - a unique step in our country.

A training programme on "Ornamental Fish Breeding \& Culture" at Dakshin Dinapur, West Bengal was a 3 days training programme and $87.50 \%$ the participants had an existing medium-level knowledge on ornamental fishes and culture. About $40 \%$ of the trainees were women and in post-training $62.50 \%$ of them gained high level knowledge in ornamental fish culture and maintenance (Goswami and Dana 2012).

\section{Tamil Nadu}

Tamil Nadu, a coastal state with Chennai, the state capital is one of the important metropolitan cities in India. It is the second largest producer of ornamental fishes and have more exposure and involvement in rural and women development via ornamental fish culture. Kolathur is a village from suburbs of Chennai, and is already on the world radar for ornamental fish culture (Felix, 2009). As an encouragement and livelihood 
for the people at Kolathur, TNJFU (Tamil Nadu Dr. J. Jayalalitha Fisheries University) has started the "Aquatic Rainbow Technology Park (ARTP)". The main aim of this is to increase the people's interest into the sector by providing demonstrations and information on the culture and maintenance of various ornamental fish species and live feed.

The study conducted by Shaleesha et al. (2000) reported to create a model for the development of rural women through backyard OFB (ornamental fish breeding). In this model, the women were facilitated with concrete tanks (3 nos.), feed, broodstock and required accessories. This helped the rural women to market the fishes 17-20 times more within introductory phase of two years.

Tamil Nadu also has immense opportunities in training women for marine ornamental fishes along the Gulf of Mannar and Palk Bay. Marine ornamental fish culture is having great scope as $98 \%$ of them comes from wild catch. Successful marine ornamental fish culture by fisherwomen SHGs in Ramanathapuram district has been possible after providing training and extension activities by Mandapam Regional Centre of ICARCMFRI (Johnson et al. 2016). The centre provided technical guidance on various aspects of ornamental fish culture to the fishers in different villages in the district under GOMBRT (Gulf of Mannar Biosphere Reserve Trust) funded project on 'Capacity building on seed production of selected marine ornamental fishes to fisherwomen in Gulf of Mannar region'. Out of 114 fisherwomen attended the training programme, 23 of them were able to take this sector as a livelihood option. Also, they could earn a gross revenue of Rs. 30,000 within a period of two months. Under TNJFU, Ramanathapurm Centre for Sustainable Aquaculture (RCeSA), Mandapam organized training on marine ornamental fish culture, seaweed culture etc. mainly to focus on women empowerment and regional development.

\section{Maharashtra}

Maharashtra has infinite resources in terms of rivers and reservoirs. The state capital has one of the major ports of India and the Kurla market in Mumbai is famous for fish market as well as ornamental fish sales and accessories.
ICAR-CIFE (Central Institute of Fisheries Education) had taken up the upliftment of tribal living in the vicinity of the Dimbhe reservoir (Dube and Lakra, 2012). Initially, they set up an SHG containing 22 women after awareness workshop and training programmes. They reared ornamental fishes such as gold fish, koi carps and angel fish in $3 \mathrm{~m} \times 3 \mathrm{~m} \times 3 \mathrm{~m}$ cages. The yield form the reared cages were sold in a shop in Dimbhe village. From this, they were able to earn ₹ 9580 every month thus empowering them till today.

\section{The Reasons for Affordability of Ornamental Fish Culture by Women}

Women in most backward societies or rural areas are lacking in financial and educational resources and hence they are least aware of their opportunities. The following are the reasons for a women group to implement ornamental fish culture (Mercy and Kumar, 2014).

* It is an easily adoptable technology.

* It requires only small amount of investments.

* Increasing demand for aquarium fishes in domestic and international markets.

* Attractive prices for different varieties if maintained in healthy conditions.

* Higher profitability from the venture even in small scale units.

* Provision of special schemes for its promotion in national and state level.

* Stress relief.

Even though men hold an upper hand in any new field, the ornamental fish farming is a sector equally advantageous to women as well; because it may be maintained in smaller cement cisterns or small lined backyard ponds in the vicinity of the house itself (Sharma, 2020). Furthermore, it requires less space and skill, thereby reducing the need to allocate specific time for its maintenance and care. It can also be maintained by unskilled people with a few days of training (Ghosh et al. 2003). The ornamental fisheries sector always has the potential to improve the social status of a family by increasing the income of the beneficiaries. 


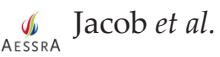

\section{Support from Funding Agencies}

The ornamental fisheries sector is an area that has received much attention in the past and also in the recent days. It has been receiving specific funding for development of new units or up scaling of existing units. Special consideration is given for women as individuals and also for the women cooperative societies and SHGs in various states without much condition on the eligibility criteria (Nune, 2008). The major fund provider is the NFDB (National Fisheries Development Board, Hyderabad), NABARD (National Bank for Agriculture and rural Development) and the MPEDA, Kochi (Devi et al. 2016). PMMSY also have many lucrative funding options for anybody interested in ornamental fish culture with the AQUARAINBOW vision-2030 (DoF, 2020). Under PMMSY for development of ornamental and recreational fisheries, ₹ $30.30 \mathrm{Cr}$. have been allotted; this is mainly for the creation and promotion of backyard ornamental fish rearing unit in freshwater and marine water areas.

\section{Why Should Women Take Up Ornamental Fishery?}

Due to inadequate/stable income in the initial stages, men/farmers cannot afford to take risks. The returns on innovation should be high to offset risk associated with its adoption and the extra labour required. Ornamental fish culture is flourishing as it is realized a hobby and it can become a profitable business as less literate people can be trained in culture techniques to achieve good production at lesser investment when compared to other opportunities (Sharma, 2020). Ornamental fish culture has been ventured among the landless rural women for additional supplementary income (Ninawe and Diwan, 2005). For instance, when the landless women of rural India provided with just simple live bearers, they could able to earn an average of ₹ 300-500/- in addition to their normal wages from their daily occupation.

\section{Difficulties Faced by Women- Problems to be Addressed}

Women are always considered a weaker section in our society and hence they face a number of difficulties in all their activities in each field. Some of the most prominent ones are as follows:
* Lack of self confidence.

* Limited access to networks and awareness campaigns.

* Socio-cultural barriers.

* Lack of free mobility.

* Improper knowledge in business.

* Insufficient financial support.

* Family obligations.

\section{CONCLUSION}

Women as entrepreneurs can also contribute much and increase the national gross productivity. They assist in generating employment opportunities for other women who are in need of help. They can develop a sense of economic independence in their children and other women. Overall, it improves the standard of living of women communities, leading to self-confidence. In addition, it spreads a message of enhanced awareness and sense of achievement among women. Women fit into this particular ornapreneurial avenue owing to their enormous innate patience provided they are trained and considerable effort is required to capture the existing and latent ornapreneurial potential of women in this sector.

\section{REFERENCES}

Devi, B.N., Krishnan, M., Ananthan, P.S. and Pawar, N. 2016. Socio-economic and livelihood profile of ornamental fish producers in India-The DFID approach. Econ. Affa., 61(2): 239.

DoF, 2020. Promotion of ornamental fisheries under PMMSY (Pradhan Mantri Matsya Sampada Yojana). Department of Fisheries, Govt. of India.

Dube, K. and Lakra, S. 2012. Women empowerment through ornamental fish culture in cages: A success story at Dimbhe reservoir, Maharashtra. In: National Seminar on Mountain Fisheries: Challenges and Opportunity for Livelihood Security, November, 2012. DCFR, Uttarakhand, India, pp. 31-35.

FAO, The State of World Fisheries and Aquaculture - 2020 (SOFIA), Rome, Italy: Food and Agriculture Organization, 2020.

Felix, S. 2009. Developing Ornamental Aquaculture (Aquariculture) Present Scenario and Scope in Tamil Nadu. Fishing Chimes, 29: 8-9. 
Ghosh, A., Mahapatra, B.K. and Datta, N.C. 2003. Ornamental fish farming-successful small scale aqua business in India. Aquacul. Asia, 8(3): 14-16.

Goswami, B. and Dana, S.S. 2012. Ornamental fish breeding and culture-an impact analysis. Exploratory Anim. and Medical Res., 1(2): 151-155.

Goswami, B. 2011. Impact of training on ornamental fish breeding and culture of fish farmers self-help group. Journal of Aquacul. in the Tropics, 26(3/4): 147.

Harper, S., Zeller, D., Hauzer, M., Pauly, D. and Sumaila, U.R. 2013. Women and fisheries: Contribution to food security and local economies. Marine Policy, 39: 56-63.

Johnson, B., Nazar, A.A. and Jayakumar, R. 2016. Analysis of training effectiveness of marine ornamental fish culture training programmes. Marine Fisheries Information Service; Technical and Extension Series, 229: 3-7.

Matthews, E. 1993. Women and fishing in traditional Pacific Island cultures. In Workshop on People, Society and Pacific Islands Fisheries Development and Management: Selected Papers. Inshore Fisheries Research projects Technical Document (No. 5, pp. 29-33).

Ninawe, A.S. and Diwan, A.D. 2005. Women in fisheries sector and entrepreneurship development: steps for improvement. Women Empowerment in Fisheries, pp. 1-16.

Nune, S.R. 2008. Role of aquaculture in poverty reduction and empowerment of women in India through the medium of selfhelp groups.

Pandey, P.K. and Mandal, S.C. 2017. Present status, challenges and scope of ornamental fish trade in India. In Conference: Aqua Aquaria India, at Mangalore.

Raja, K., Aanand, P., Padmavathy, S. and Sampathkumar, J.S. 2019. Present and future market trends of Indian ornamental fish sector. Int. J. Fisheries and Aquatic Stu., 7(2): 6-15.
Raja, S., Babu, T.D., Nammalwar, P., Jacob, C.T. and Dinesh, K.P.B. 2014. Potential of ornamental fish culture and marketing strategies for future prospects in India. Int. J. Biosci. Nanosci., 1(5): 119-125.

Satam, S.B., Sawant, N.H., Ghughuskar, M.M., Sahastrabuddhe, V.D., Naik, V.V., Pagarkar, A.U., Chogale, N.D., Metar, S.Y., Shinde, K.M., Sadawarte, V.R. and Sawant, A.N. 2018. Ornamental fisheries: a new avenue to supplement farm income. Adv. Agric. Res. Tech. J., 2(2): 193-197.

Shaleesha, A. and Stanley, V.A. 2000. Involvement of rural women in aquaculture: An innovative approach. Naga, The ICLARM Quarterly, 23(3): 13-17.

Shaleesha, A., Stanley, V.A., Nagaraja, C. and Rajakani, S. 2000. An illustrative module for rural women in aquaculture: backyard ornamental fish breeding and marketing. Indian Farm., 50(4): 9-29.

Sharma, M. 2020. Ornamental fish rearing and breeding-a new dimension to aquaculture entrepreneurship in Himachal Pradesh. Int. J. Fish. Aquat. Stud., 8: 157-162.

Sharma, Y. 2013. Women entrepreneur in India. IOSR J. Busi. Mgt., 15(3): 9-14.

Siason, I., Tech, E., Matics, K.I., Choo, P.S., Shariff, M., Heruwati, E.S., Susilowati, T., Miki, N., Shelly, A.B., Rajabharshi, K.G. and Ranjit, R. 2002. Women in fisheries in Asia.

Singhal, V. 2016. Empowerment of Women (Review of Literature). Book entitled:" Women Empowerment in IndiaProblems and Challenges" Author: Dr. Vipin Kumar Singhal ISBN, pp. 978-93.

TVA, Mercy and Ambilikumar, V. 2015. Sustainability of women entrepreneurs in ornamental fish culture at Kumbalam panchayat, Ernakulam district, Kerala state, India. 
